\title{
Improving the Mechanical Behavior of a Helicopter Tail Rotor Blade Through the Use of Polyurethane Foams
}

\author{
ANDREI DANIEL VOICU ${ }^{1}$, ANTON HADAR ${ }^{1,2,3}$, DANIEL VLASCEANU1* \\ ${ }^{1}$ University Politehnica of Bucharest, Department of Strength of Materials, 313 Splaiul Independentei, 060032, Bucharest, \\ Romania \\ ${ }^{2}$ Academy of Romanian Scientists, 54 Splaiul Independentei, 050094, Bucharest, Romania \\ ${ }^{3}$ Technical Sciences Academy of Romania, 26 Dacia Blvd., 010413, Bucharest, Romania
}

\begin{abstract}
The tail rotor blade represents a very important component in the structure of any helicopter, being subjected to many aerodynamic loads. The integrity of this component is essential for maintaining flight safety and improving its characteristics can increase the overall performance of the helicopter. Thus, in some cases, some improvements can be made to the structure, in order to reduce the weight of the component and to improve its mechanical properties and its reliability in flight. The current paper presents a comparative result analysis in the study of the tail rotor blade of the IAR 330 helicopter, where the honeycomb hexagonal core made of aluminum alloy is replaced with a full structural core made of polyurethane foam. The result of the analysis is of practical importance, because it shows the benefits of using polymers in the construction of helicopter rotor blades and similar structures.
\end{abstract}

Keywords: helicopter tail rotor blade, honeycomb structure, polymers, polyurethane foam, finite element method

Despite numerous advantages that composite materials exhibit over metallic structures, some aircrafts haven't yet made the full transition towards imbedding composite structures in key areas. One of these aircrafts is the multipurpose IAR330 helicopter, currently used by the Romanian Air Force, which is equipped with composite main rotor blades and metal tail rotor blades. Some of the advantages of composite materials, in comparison to traditional ones are: better dimensional stability, a decrease in the mass of the structure, and improved mechanical properties, such as resistance to static and dynamic loads [1].

The tail rotor blade of a helicopter is the main component of the tail rotor, which has the purpose of maintaining the directional stability of the helicopter by countering the torque effect created by the main rotor [2].

The internal structure of the studied blade is composed of a metallic spar which runs across the whole length of the blade and a honeycomb core, incorporating numerous hexagonal cells. Due to this fact, the geometrical complexity of the structure increases and consequently the number of contact areas between structural components, also leading to a significantly larger processing time for the numerical simulation.

Honeycomb structures used in engineering applications are structures inspired from the natural environment, allowing a very large reduction in the amount of materials used, in order to achieve a structure with minimal weight and/or minimal cost. A wide variety of cell shapes can be used, depending on the purpose of the whole structure and depending on the requirements which must be met.

In aerospace industry, honeycomb structures are used for a very wide variety of applications in the form of sandwich panels, thanks to their high specific strength. They can be used in structural assemblies such as wings, rudders, vertical and horizontal stabilizers, elevators, spoilers and fuselage.

The mechanical properties of hexagonal cell honeycombs vary with the direction of the applied load (orthotropic behavior). These aluminum alloy structures have a high compression strength, generally higher than that of other inner core materials such as foams, due to the ability of the cell walls to support each other [3].

The mechanical behavior of these materials has been studied by different authors, using as well numerical simulations as experimental methods, with the purpose of improving their properties [4-6]. Also, a very important issue regarding the maintenance process of helicopter blades is the possibility of increasing the life cycle of tail rotor blades [7]

Taking into account the numerous processing hours necessary to complete a numerical simulation analysis for a 1:1 scale ratio of the tail rotor blade, it would be the best to consider an alternative approach to the analysis, which requires less processing time and leading to satisfying results.

The main purpose of this study is to analyze the possibility of replacing the aluminum alloy honeycomb inner core of the tail rotor blade with a polyurethane foam core and to analyze the impact of this modification on the numerical simulation results. This modification allows a simpler approach in manufacturing the blade and also in realizing the numerical simulation.

The current study is based on the sandwich structure of a full metallic aluminum alloy tail rotor blade of the IAR 330 helicopter currently in use by the Romanian Air Force, and can provide certain advantages regarding the use of composite materials in studying the mechanical behavior of metallic tail rotor blades.

\section{Experimental part}

Materials and methods

Blade structure and materials

The major structural components of the tail rotor blade of the IAR330 helicopter are presented in figure 1.

The spar is the primary structural element of the blade, which gives most of its stiffness and starts from the open end of the blade, where it is attached on the helicopter, and runs across the entire length of the blade, through the 


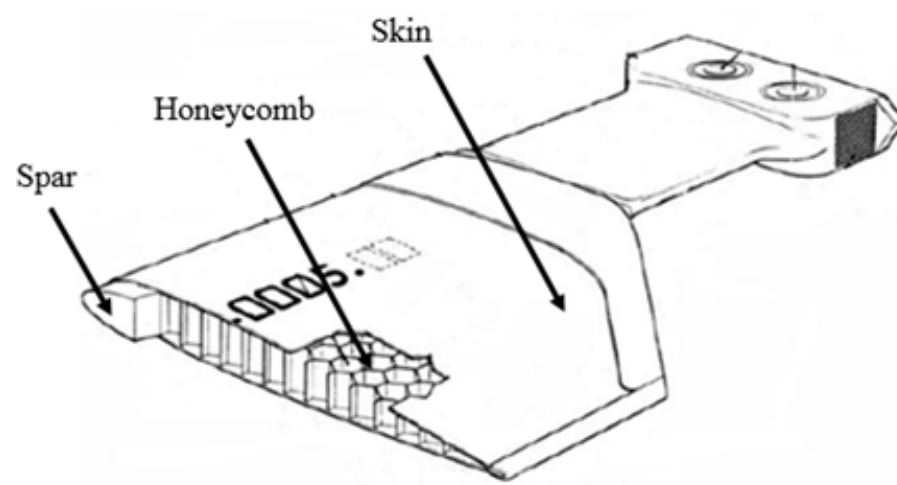

Fig. 1. Inner structure of the IAR330 tail rotor blade

NACA0012 symmetric airfoil. The material used for the spar is 6061-T6511 aluminium alloy, manufactured by extrusion.

The honeycomb core of the blade is located inside the NACA0012 airfoil skin, in the remaining space created by the skin and the spar of the blade. It is defined by the following NIDA specification: NIDA 2.3-3/8-.0015 P(5052), where the material used for manufacturing the honeycomb is a 5052 aluminium alloy, a material with high corossion resistance.

The blade skin incorporates two major inner structural components, giving the blade its aerodynamic shape. It is manufactured from a $0.5 \mathrm{~mm}$ 6061-T4 aluminum alloy metal sheet.

The main elastic and mechanical properties of the materials used in the construction of the blade are presented in table 1 [8-10].

Although metal blades were an innovation at their time providing a more reliable structure, especially with the embedding of honeycomb cores, today composites are the predominant materials used for blade manufacturing, due to their superior structural properties and to the multitude of possibilities of combining them, with the purpose of obtaining the most suitable structure for a certain application. Therefore, improving the current structure of the blade by replacing one of its components with a polymer based structure can provide a more reliable structure with a longer lifespan.

\section{D Modelling}

The tail rotor blade was designed in Ansys Workbench using the NACA0012 aerodynamic airfoil developed by the National Advisory Committee for Aeronautics. It is characterized by a symmetric shape along the chord line and has the maximum thickness located at $12 \%$ of its chord. The blade has a length of approximately $1244.3 \mathrm{~mm}$ and the chord of the airfoil measures approximately 185.5 $\mathrm{mm}$. The total mass of the real blade as stated by the manufacturer is approximately $2.680 \mathrm{~kg}$.

The tail rotor blade with a diameter of $3.042 \mathrm{~m}$ uses four blades and rotates at a speed of approximately $1278 \mathrm{rpm}$, in normal flight conditions.

In realizing this comparison two geometrical models of the inner core are taken into account. The first model, presented in figure 2 , is made of an aluminum alloy honeycomb core.

This version of the model uses hexagonal cells, with NIDA 2.3-3/8-.0015 $\mathrm{P}(5052)$ specifications, and is characterized by a material density of $36.842 \mathrm{~kg} / \mathrm{m}^{3}$, with the dimensions presented in figure 2 .

In figure 3, the simplified version of the model is depicted, with a full polyurethane foam inner core replacing the honeycomb core shown in figure 2 .

The material used to replace the honeycomb core is the Rohacell WF structural foam, which has been designed for use primarily in aerospace and aeronautical applications. It is used frequently in the main and tail rotor

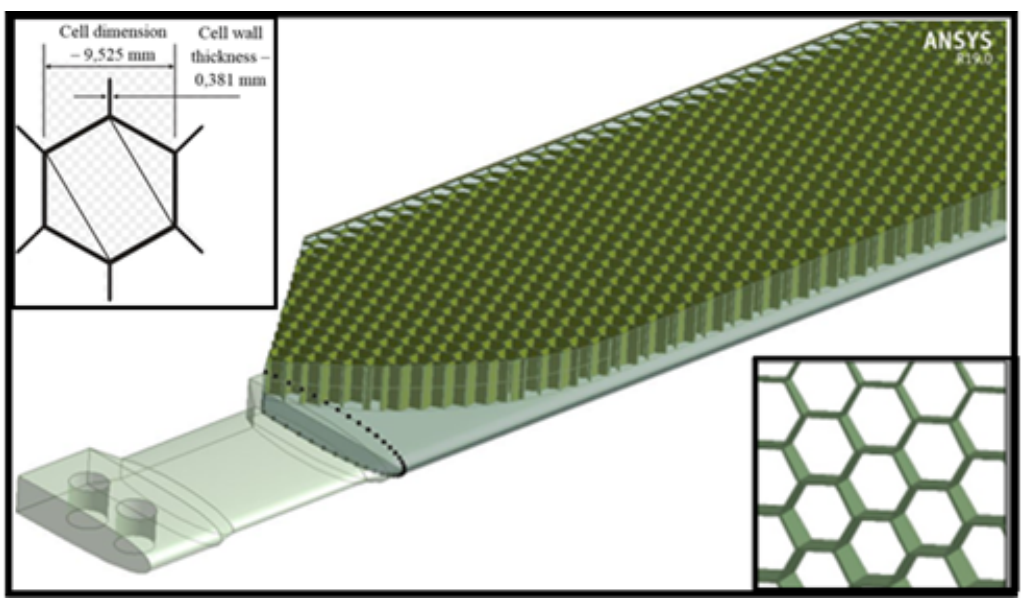

Fig. 2. Actual honeycomb inner core design of the tail rotor blade

\begin{tabular}{|c|c|c|c|}
\hline Property & $\begin{array}{c}\text { Material } \\
\begin{array}{c}\text { alloy } \\
\text { (Spar) }\end{array}\end{array}$ & $\begin{array}{c}5052 \text { aluminium alloy } \\
\text { (Honeycomb) }\end{array}$ & $\begin{array}{c}\text { 6061-T4 aluminum alloy } \\
\text { (Skin) }\end{array}$ \\
\hline Density & $2700 \mathrm{~kg} / \mathrm{m}^{3}$ & $2680 \mathrm{~kg} / \mathrm{m}^{3}$ & $2700 \mathrm{~kg} / \mathrm{m}^{3}$ \\
\hline Ultimate Tensile Strength & $310 \mathrm{MPa}$ & $228 \mathrm{MPa}$ & $241 \mathrm{MPa}$ \\
\hline Tensile Yield Strength & $276 \mathrm{MPa}$ & $193 \mathrm{MPa}$ & $145 \mathrm{MPa}$ \\
\hline Modulus of Elasticity & $68.9 \mathrm{GPa}$ & $70.3 \mathrm{GPa}$ & $68.9 \mathrm{GPa}$ \\
\hline Poisson's Ratio & 0.33 & 0.33 & $96.5 \mathrm{MPa}$ \\
\hline Fatigue Strength & $96.5 \mathrm{MPa}$ & $117 \mathrm{MPa}$ & $26 \mathrm{GPa}$ \\
\hline Shear Modulus & $26 \mathrm{GPa}$ & $25.9 \mathrm{GPa}$ & $165 \mathrm{MPa}$ \\
\hline Shear Strength & $207 \mathrm{MPa}$ & $138 \mathrm{MPa}$ & \\
\hline
\end{tabular}

Table 1

ELASTIC AND MECHANICAL PROPERTIES OF THE MATERIALS USED FOR THE IAR330 TAIL ROTOR BLADE 


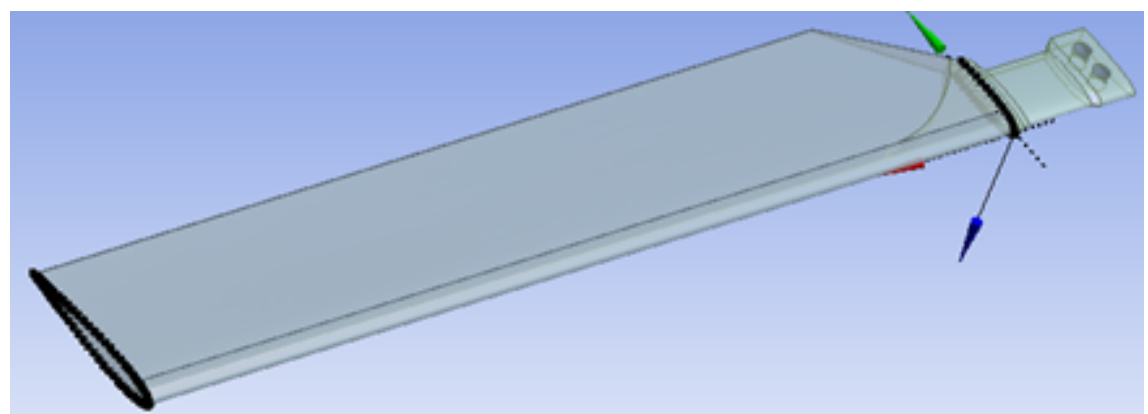

Fig. 3. Simplified full inner core version of the tail rotor blade

blades, as well as fuselage panels by various aircraft manufacturers such as Airbus or Boeing [11].

The main elastic and mechanical properties of three different polyurethane rigid foams produced by Rohacell for aerospace applications are presented in table 2.

The material used to replace the honeycomb core is the Rohacell WF structural foam, which has been designed for use primarily in aerospace and aeronautical applications. It is used frequently in the main and tail rotor blades, as well as fuselage panels by various aircraft manufacturers such as Airbus or Boeing [11].

The main elastic and mechanical properties of three different polyurethane rigid foams produced by Rohacell for aerospace applications are presented in table 2.

\section{Numerical analysis}

In order to study the two designed models under a specific load and to draw a conclusion regarding their behavior, they are modeled within a static structural analysis, where the surfaces of the two separate blade models are loaded with an aerodynamic pressure generated by the air flowing around the blade, at a speed of $206.5 \mathrm{~m} /$ $\mathrm{s}$, equivalent to the blade tip speed rotating at $1278 \mathrm{rpm}$.

The fluid flow analysis of the studied blade reveals pressures of about $26.46 \mathrm{kPa}$ on the leading edge of the blade, and of approximately $13.08 \mathrm{kPa}$ at the trailing edge. The highest values of these pressures are obtained on the leading edge and on the lower part of the spar of the blade, due to low aerodynamic properties of the area.

The key variable element of the analysis is the incidence angle of the blade. Its importance is given by the fact that the change of incidence angle results in a change in the pressure distribution on the inner and outer faces of the blade. During flight, this parameter varies in the following interval: $+2.5^{\circ} \div-15.5^{\circ}$. The most important incidence values are:

- $0^{\circ}$ - the value where the pressure distribution is symmetrical on both sides of the blade;

- $-6.5^{\circ}$ - the value where helicopters maintain their stable position around their vertical axis;

- $-15.5^{\circ}$ - the maximum negative incidence to be achieved.

The value of the incidence angle chosen to be studied in the numerical analysis comparison is $0^{\circ}$.

The pressure distribution obtained in the fluid flow analysis can be observed in figure 4 . They are identical for each incidence angle, regardless of the design of the inner core of the blade.

\section{Results and discussions}

The equivalent stress distribution depicted in figure 5 reveals that the areas with stress concentrators are located at the foot of the blade and inside the honeycomb core, where the hexagonal cells are attached to the skin of the blade (fig. 6).

\begin{tabular}{|c|c|c|c|}
\hline Material & $\begin{array}{c}\text { ROHACELL } \\
71 \mathrm{WF}\end{array}$ & $\begin{array}{c}\text { ROHACELL } \\
110 \mathrm{WF}\end{array}$ & $\begin{array}{c}\text { ROHACELL } \\
200 \mathrm{WF}\end{array}$ \\
\hline Property & $75 \mathrm{~kg} / \mathrm{m}^{3}$ & $110 \mathrm{~kg} / \mathrm{m}^{3}$ & $205 \mathrm{~kg} / \mathrm{m}^{3}$ \\
\hline Demsity & $1.7 \mathrm{MPa}$ & $3.6 \mathrm{MPa}$ & $9 \mathrm{MPa}$ \\
\hline Tensile Strength & $2.2 \mathrm{MPa}$ & $3.7 \mathrm{MPa}$ & $6.8 \mathrm{MPa}$ \\
\hline Tensile Modulus & $105 \mathrm{MPa}$ & $180 \mathrm{MPa}$ & $350 \mathrm{MPa}$ \\
\hline Elongation at Break & $3.0 \%$ & $3.0 \%$ & $3.5 \%$ \\
\hline Shear Modulus & $42 \mathrm{MPa}$ & $70 \mathrm{MPa}$ & $150 \mathrm{MPa}$ \\
\hline Shear Strength & $1.3 \mathrm{MPa}$ & $2.4 \mathrm{MPa}$ & $5 \mathrm{MPa}$ \\
\hline
\end{tabular}

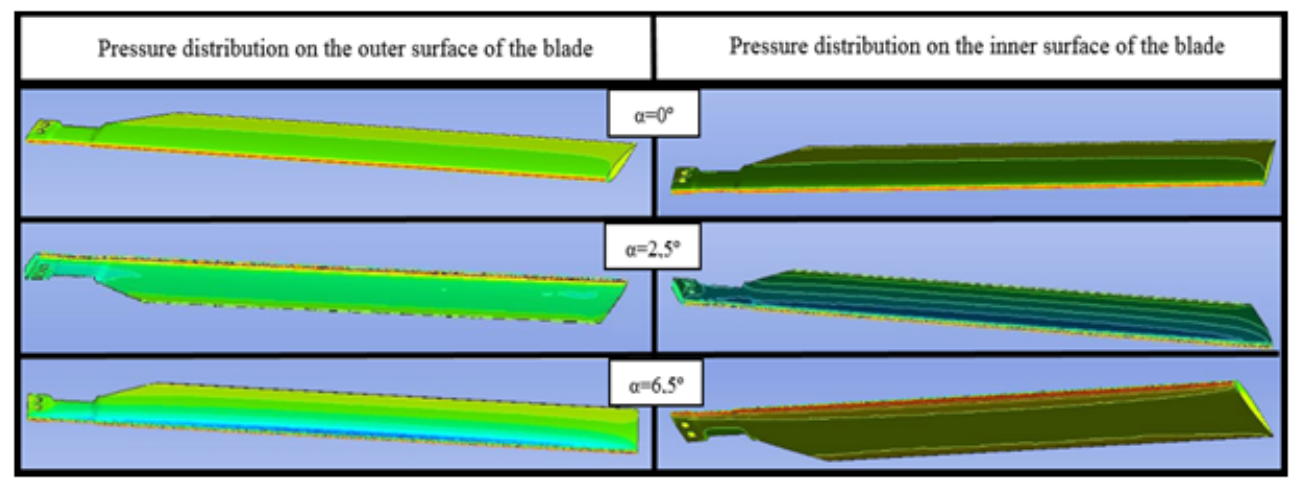

REV.CHIM. (Bucharest) $\bullet 70 \diamond$ No. $11 \diamond 2019$
Table 2

ELASTIC AND MECHANICAL PROPERTIES FOR DIFFERENT ROHACELL WF STRUCTURAL FOAMS

Fig. 4. Pressure distribution on the blade surfaces for different incidence angles 

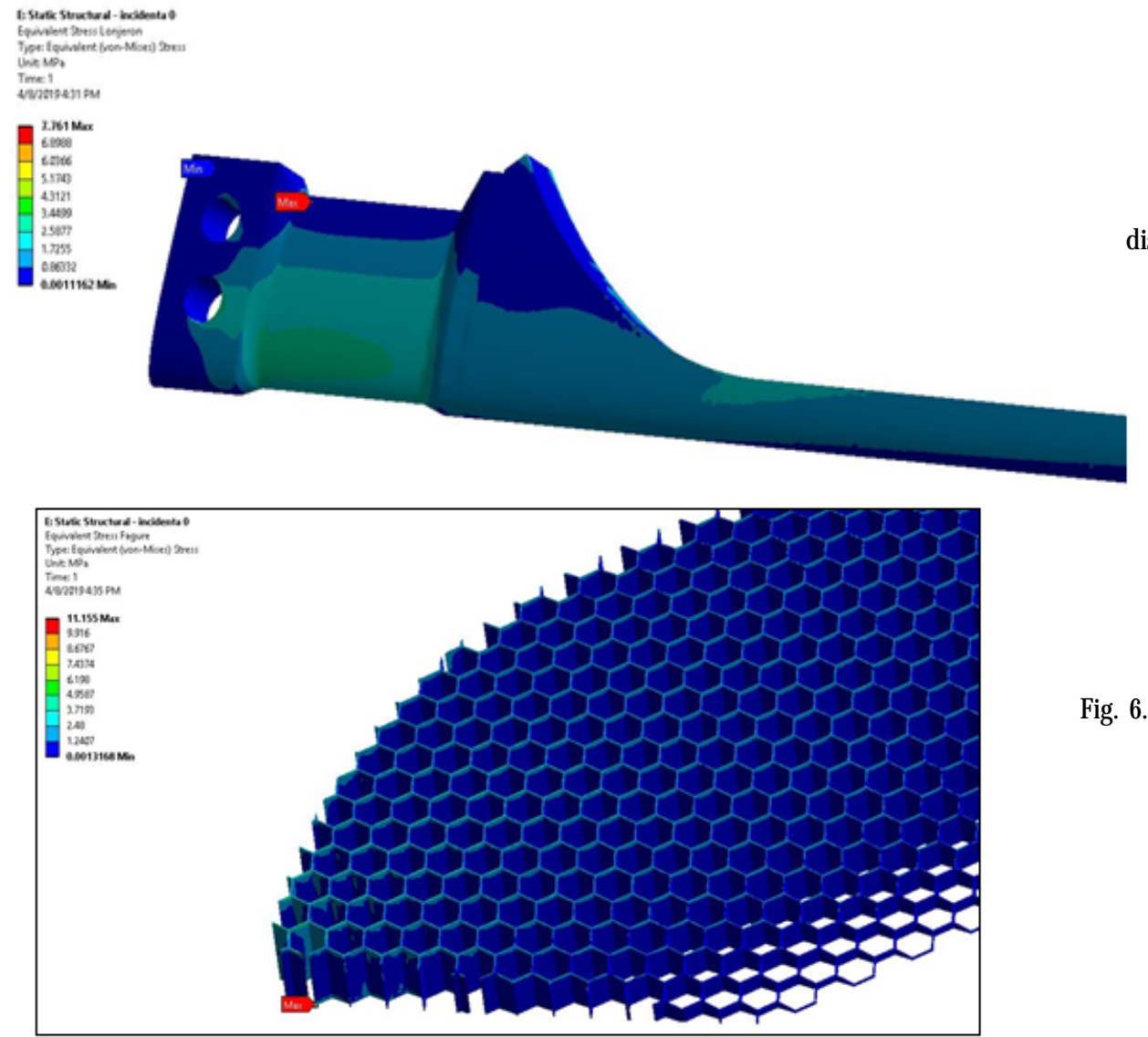

Fig. 5. Equivalent stress

distribution on the spar of the blade

Fig. 6. Equivalent stress distribution on the honeycomb core

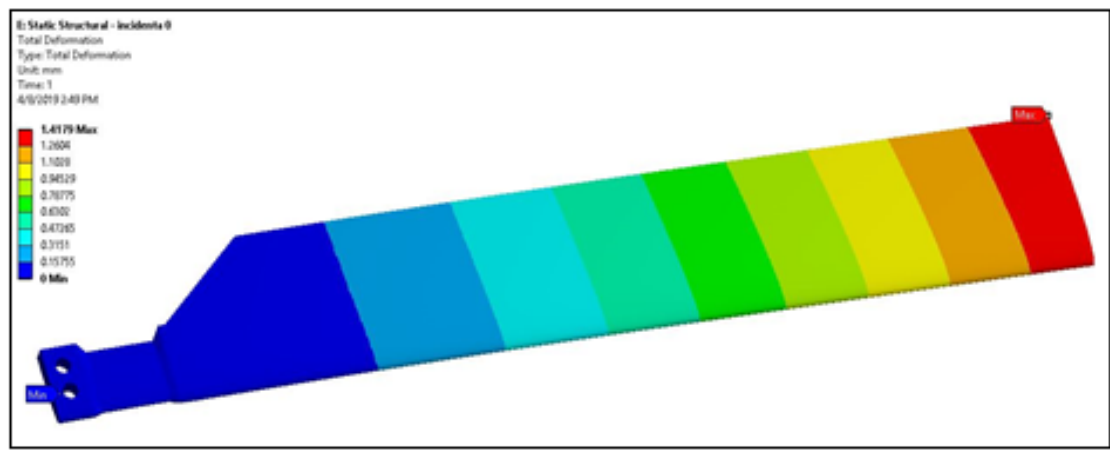

Fig. 7. Deformation distribution of the blade with an aluminum alloy honeycomb core

The deformed shape of the blade is presented in figure 7 and the maximum deformation occurs at the tip of the blade, regardless of the incidence angle of the blade.

The maximum deformation of the blade with a polyurethane foam core is presented in figure 8 . A slight increase can be observed in the total deformation of the blade, which occurs at the tip of the blade, but it does not overcome the elasticity limit of the blade.

The total deformations obtained from the static structural analysis for the same pressure distribution on

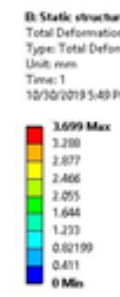

the blade, are presented in table 3 , for the three different types of polyurethane foam cores.

The results presented in table 3 reveal an increase in the maximum total deformation of the blade of approximately $2.2 \mathrm{~mm}$. Although it might seem as a large increase compared to the $1.418 \mathrm{~mm}$ deformation obtained for the aluminum honeycomb core blade, taking into account that the simulation has been realized for the maximum aerodynamic load which occurs during flight, it is safe to say that the polyurethane foam core is a viable solution for replacing the honeycomb core of the blade.

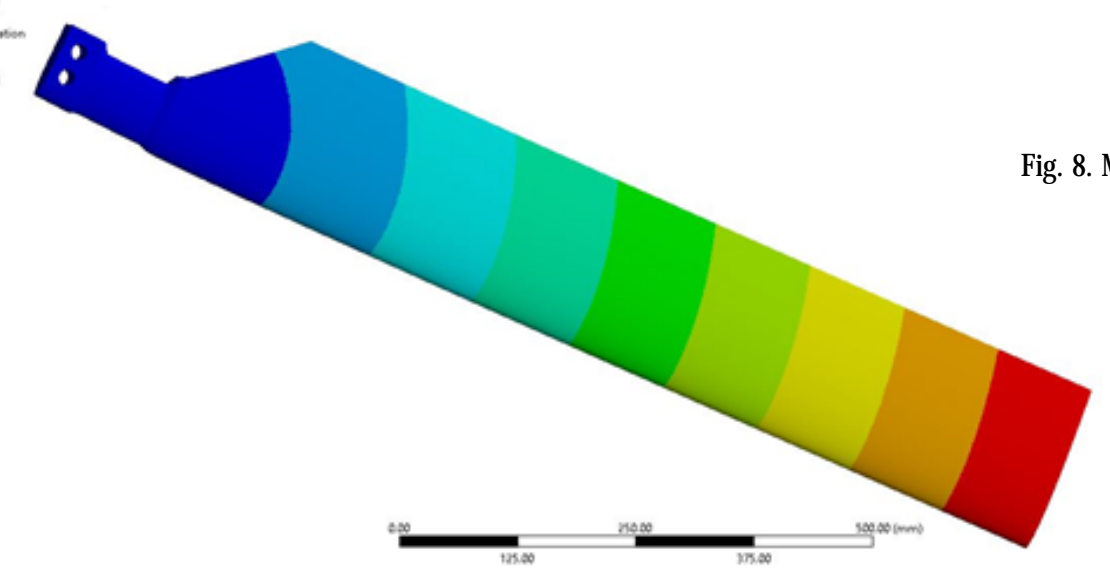




\begin{tabular}{|c|c|c|c|c|}
\hline Inner core type & $\begin{array}{c}\text { Aluminum } \\
\text { honeycomb } \\
\text { inner core }\end{array}$ & $\begin{array}{c}\text { Rohacell 71 WF } \\
\text { polyurethane } \\
\text { foam core } \\
\text { Results }\end{array}$ & $\begin{array}{c}\text { Rolyurethane } \\
\text { foam core }\end{array}$ & $\begin{array}{c}\text { polyurethane foam } \\
\text { core }\end{array}$ \\
\hline $\begin{array}{c}\text { Maximum total deformation } \\
\text { of the blade [mm] }\end{array}$ & 1.418 & 3.699 & 3.679 & 3.634 \\
\hline
\end{tabular}

Table 3

COMPARISON OF THE DEFORMATIONS OBTAINED FROM THE NUMERICAL ANALYSIS

Although it is exposed to a slightly higher deformation and stress, the polyurethane foam core possesses many of the advantages that composite materials have over traditional materials, such as: a decrease in the total mass of the blade, which reduces the stress on the entire tail rotor assembly, a higher lifespan of the blade and the absence of corrosion.

For the three studied polyurethane foams, the results show very little differences between the materials, making the Rohacell 71 WF polyurethane foam the most costefficient material which can be used to substitute the traditional aluminum honeycomb core.

\section{Conclusions}

The analysis is performed at a constant wind speed of $206.5 \mathrm{~m} / \mathrm{s}$, due to the intention of comparing the pressure load obtained from the fluid flow analysis to the data obtained by studying the flow around the blade inside the aerodynamic tunnel.

As expected, the analysis shows comparable values for all the studied cases, but with more advantages being obtained from the usage of polyurethane foams, which are described by a smaller mass and a higher life span than the aluminum core.

The dimensions of the tail rotor blade are an approximation of the realistic model and in the modelling process only the major structural components were taken into account.

Although the aluminum honeycomb core is characterized by a higher resistance to deformation, the foam core possesses numerous other advantages which makes it a more desirable material and structure to replace the already existing one. Some of these advantages are: a simpler manufacturing complexity, faster calculation times for numerical analysis used to study the mechanical behavior of the tail rotor blade, decrease in the total mass of the blade, a higher lifespan of the blade and the absence of corrosion.

Acknowledgements: This work is supported by the project ANTREPRENORDOC, in the framework of Human Resources Development Operational Program 2014-2020, financed from the European Social Fund under the contract number 36355/23.05.2019 HRD OP/380/6/13 - SMIS Code: 123847.

\section{References}

1. HADAR, A., Structuri din composite stratificate (Structures made of laminated composites), Romanian Academy Publishing House \& AGIR Publishing House, Bucharest, 2002, ISBN 973-27-0961-8 and ISBN 9738466-25-3

2. VLASCEANU, N., Elicoptere. Caracteristici si performante (Helicopters. Characteristics and performances), ATM Publishing House, Bucharest, 1983

3. HADAR, A., CORMOS, R., PETRESCU, H.-A., Numerical evaluation of the behavior of a multilayered honeycomb composite material in an aeronautical engineering application, Journal of Engineering Sciences and Innovation, Vol. 3, Issue 1/2018, p. 1-9

4. SIMHACHALAM NAIDU, K., SRIRAM, M., SHISHIRA NAYANA, B., Modeling and Analysis of a Helicopter Rotor Blade, International Journal of Science and Research, Volume 4, Issue 8, August 2015, p. 324-328

5. BALAJI, K., GRACEKUMAR, P., MAHIMAIPRABHU, K., MANIKANDAN, M., RAGHUL, R., Design and Development of Main Helicopter Rotor Blade, International Journal for Research in Applied Science \& Engineering Technology (IJ RASET), Volume 5, Issue IV, April 2017, p. 74-77, ISSN: 2321-9653

6. GARINIS, D., DINULOVIÆE, M., RASUO, B., Dynamic Analysis of Modified Composite Helicopter Blade, FME Transactions, 40, 2012, p. 63-68

7. BALASK, M., ENDROEZI, G., VERES, J., MOLNIR, Gy., KOROSI, F., Research of Extension of the Life Cycle of Helicopter Rotor Blade in Hungary, RTO A VT Specialists Meeting on Life Management Techniques for Ageing Air Vehicles, RTO-MP-079 (II), 2003

8.***http://asm.matweb.com/search/SpecificMaterial.asp?bassnum $=$ ma6061t4, 14 august 2019

9.***http://asm.matw eb.com/search/SpecificMaterial.asp? bassnum $=$ ma6061t6, 14 august 2019

10.*** http://www.ct-sim.eu/honeycombcore/nida-aluminumhoneycomb-technical-doc-v06-en. pdf, 14 august 2019

11.*** https://ww w.rohacell.com/product/rohacell/en/productsservices/rohacell-wf/, 14 august 2019

Manuscript received: 11.11 .2019 